\title{
NON-DISCRIMINATION OF PART-TIME AND FIXED-TERM WORKERS IN RECENT EU CASE LAW
}

\begin{abstract}
This paper discusses the case law of the CJEU over the past five years on the principle of nondiscrimination in relation to part-time and fixed-term workers. This case law shows certain shortcomings when it comes to the principle of non-discrimination of part-time and fixed-term workers, partly because the CJEU's room for interpretation itself of course is limited by EU regulations and partly because, as we shall see below, its own way of interpreting them. The contribution is structured as follows. First, a brief overview is provided on the limited reach of the principle of non-discrimination as framed in the Framework Agreements. This is followed by an analysis of the case law on part-time work and, after that, the case law on fixed-term work. The conclusion addresses some of the main issues that raise due to the Framework Agreements' set-up and the CJEU's interpretation of them.
\end{abstract}

Słowa kluczowe: praca w niepełnym wymiarze czasu pracy, praca na czas określony warunki pracy, zakres dyskryminacji

Key words: part-time work, fixed-term work, employment conditions, non-discrimination

\section{Introduction}

Despite the fact that current developments in the world of work imply that flexible work relationships are inexorably on the rise, the standard employment relationship still is 'the norm,' ${ }^{2}$ at MS and at EU level. Reasons why the EU legislator, together with the social partners, has introduced regulations on atypical employment relationships, and in particular the Part-time Work and Fixed-term Work Framework Agreements, ${ }^{3}$ are

1 Also: visiting researcher at the Research Centre for Business and Law, Radboud University Nijmegen (The Netherlands). Email: miriam.kullmann@wu.ac.at.

2 E.g., European Commission, Annual Growth Survey 2016: Strengthening the recovery and fostering convergence, Communication (COM) 2015, p. 690 final.

3 Council Directive 97/81/EC of 15 December 1997 concerning the Framework Agreement on parttime work concluded by UNICE, CEEP and the ETUC [1998] OJ L14/9 and Council Directive 1999/70/ EC of 28 June 1999 concerning the framework agreement on fixed-term work concluded by ETUC, UNICE and CEEP [1999] OJ L175/43. 
twofold. First, to allow workers to balance work and family life, and, second, to allow employers to arrange work processes according to their particular needs, in a more flexible way, without obliging them to always offer workers a full-time permanent - or standard - employment contract. This, it is said, addresses the needs of businesses and workers by balancing between flexibility in working time and security for workers. Even though atypical employment relationships may have the potential to benefit employers and workers alike, the Framework Agreements contain particular mechanisms aimed at balancing between different interests at stake: to remove discrimination, to improve the quality of part-time and fixed-term work and to prevent the abuse of successive fixed-term contracts (Clauses 1 of the Framework Agreements). Rather than limiting the use of part-time work or fixed-term work, these balancing mechanisms aim to facilitate the 'adequate' use of these two forms of work.

Anne Davies helpfully discusses three 'questionable' assumptions on which the regulations on fixed-term and part-time work, that try to 'normalize' non-standard work, are based: ${ }^{4}(1)$ part-time and fixed-term work are beneficial to the worker; (2) these forms of work act as stepping stones; and (3) unequal treatment of non-permanent workers compared with standard workers as the main problem. The 'benefits argument' tends to refer to working-hours flexibility rather than the duration or stability of the work relationship. While probably benefiting part-time workers, this might not be the case for fixed-term workers, whose work periods are frequently and repetitively interrupted. The European Commission uses the 'stepping stones' argument to support the idea that the Framework Agreements are 'inclusive' instruments for those who experience difficulty in finding work or gaining access to the labour market. Non-standard work might then be used to lead - at least this is hoped for - to the sort of standard employment relationship which most people (still) seem to want. Finally, the 'unequal treatment argument' emphasizes equal treatment in terms of 'employment conditions' such as wage, health and safety, and working time. Nevertheless, a worker having a fixed-term employment contract may still experience disadvantages because of unstable employment and a part-time worker may have to work on a casual basis making it difficult to predict the working schedule. It is in particular the 'unequal treatment argument' I wish to focus on here.

The case law over the past five years, ranging from 2013 to 2018, show certain shortcomings when it comes to the principle of non-discrimination of part-time and fixed-term workers, partly because the CJEU itself of course is limited by EU regulations in its interpretation thereof and partly because, as we shall see below, its own way of interpreting them. The contribution is structured as follows. First, a brief overview is provided on the limited reach of the principle of non-discrimination as framed in the Framework Agreements. This is followed by an analysis of the case law on part-time work and, after that, the case law on fixed-term work. The conclusion addresses some

4 A. Davies, Regulating atypical work: Beyond equality, in: N. Countouris, M. Freedland (eds.), Resocialising Europe in a Time of Crisis, Cambridge University Press 2013, p. 230-249. 
of the main issues that raise due to the Framework Agreements' set-up and the CJEU's interpretation of them.

\section{The principle of non-discrimination and its limitations}

Following Clauses 4 of the Framework Agreements on Part-time and Fixed-term Work, in respect of employment conditions, part-time or fixed-term workers shall not be treated in a less favourable manner than comparable full-time or permanent workers solely because they work part-time or on a fixed-term unless different treatment is justified on objective grounds, such as the pro rata temporis principle. Three limitations can be derived from this non-discrimination provision in conjunction with the CJEU's interpretation thereof.

First, the principle of non-discrimination only applies to employment conditions, to the exclusion of social security. An alternative to using the Framework Agreement on part-time, for instance, would be to use a 'gender lens'. The difficulty here, however, is that the part-time worker has to show that the rule disadvantages ${ }^{5}$ a considerably higher percentage of women than men, or vice versa. ${ }^{6}$ Part-time workers have to show a disparate impact, which is difficult where relevant statistics are not available or are incomplete. Moreover, male part-time workers are unable to bring a claim unless the usual circumstances are reversed, i.e. that full-time in their firm are mostly female and the disadvantaged part-timers mostly male. ${ }^{7}$

Second, in order for a non-discrimination claim to be successful, the part-time or fixed-term worker needs to find a comparable full-time or permanent worker. This, however, does not include the possibility to compare with a hypothetical worker or former colleagues. ${ }^{8}$ Also, the comparable worker must be in the same establishment engaged in same or similar work or occupation (presumably same type of contract). In Wippel, also the same type of contract (as she could refuse to work, there was no comparable full-time worker); presumably also applicable in relation to fixed-term work. ${ }^{9}$ Decisive is whether part-time or fixed-term worker is in a comparable position as the full-time or permanent worker with a view to the respective employment condition; not a general comparison.

Third, where workers are treated less favourably because of their part-time or fixed-term work employment contract or relationship, this seems to indicate that no other

5 Cf. Article 2(1) (b) Directive 2006/54/EC: where an apparently neutral provision, criterion or practice would put persons of one sex at a particular disadvantage compared with persons of the other sex. 6 E.g., Case C-236/98 Örebro läns landsting ECLI:EU:C:2000:173, para 50.

7 A. Davies, EU Labour Law, Elgar European Law, Edward Elgar 2012, p. 185-186.

8 C. Barnard, EU Employment Law, $4^{\text {th }}$ ed., Oxford University Press 2012, p. 440.

9 Case C-313/02 Wippel ECLI:EU:C:2004:607. 
plausible reasons for the alleged discriminatory treatment may exist. ${ }^{10}$ Reasons not related to the type of employment relationship or contract, therefore, seem to be excluded from the scope of the non-discrimination principle. While, in the following, the case law analysis is thematically organized, I will come back to the three limitations in my conclusion.

\section{EU case law on part-time work}

The cases dealt with in the following, can be grouped in three categories, namely cases on: the conversion from part-time into full-time work; the pro rata temporis principle; and the relation with social security benefits.

\section{Conversion from part-time into full-time work: comparable situation?}

In Mascellani, ${ }^{11}$ Ms Mascellani's worked on a part-time basis, after conversion of her full-time contract, so that she could use her free time to care for her family and to undertake vocational training. Her employer, relying on Italian law, however, unilaterally (re)converted her part-time contract into a full-time contract. Thus, the question was whether this (re)conversion is discriminatory. Referring to the principle of non-discrimination, the CJEU emphasises that Clause 4 seeks to eliminate discrimination between full-time and part-time workers in respect of employment conditions. Advocate General Wahl argues that the principle of non-discrimination applies not to the 'risk for the part-time worker that the daily amount of time devoted to working may be adjusted against his will. The CJEU rejects that part-time workers and full-time workers whose contracts are converted into full-time or part-time employment are not in a comparable situation. In line with AG's Opinion, the CJEU stresses that there is a difference between the conversion of full-time work into part-time and vice versa, because reducing working time does not involve the same consequences as an increase in working time, in particular, as regards the worker's remuneration as consideration for work carried out. It should be stressed that changing working time unilaterally can harm part-time workers and full-time workers equally. While the former may not be able to combine work and family life anymore in case working time is extended, the latter may experience a loss of income. Especially this last, economically induced point, the worker's livelihood, seems relevant for the CJEU as well as the fact that the Framework Agreement obliges Member States to facilitate part-time work on a voluntary basis while also contributing to the flexible organization of working time speaking to the needs of employers and workers. Part-time work in this case already was facilitated, and it seems that once facilitated, there is no need to guarantee part-time work anymore.

10 Opinion AG Wahl Case C-361/12 Carmela Carratù v Poste Italiane SpA ECLI:EU:C:2013:620, para 53.

11 Case C-221/13 Teresa Mascellani ECLI:EU:C:2014:2286. 


\section{Pro rata temporis principle: justifying a difference in treatment}

In Österreichischer Gewerkschaftsbund, a case on calculating dependent child allowance, the Austrian Trade Union Confederation sought a declaration that part-time workers falling within the scope of the collective agreement are entitled to payment of the 'full amount of the dependent child allowance' provided by that collective agreement and not only an amount calculated on a pro rata temporis basis. ${ }^{12}$ According to the CJEU, child allowances constitute 'pay' under Art 157(2) TFEU. The legal nature of the consideration is not important for the purposes of Art 157 TFEU provided that it is granted in respect of the employment. ${ }^{13}$ Since the dependent child allowance is part of a worker's pay, it is determined by the terms of the employment relationship agreed between the worker and the employer. Thus, if a worker is employed part-time, calculating the dependent child allowance in accordance with the pro rata temporis principle is objectively justified. Quite frequently, CJEU has equated pay under the Framework Agreement with pay under the TFEU. The dependent child allowance, like a retirement pension ${ }^{14}$ or paid annual leave, ${ }^{15}$ is a divisible benefit, and the reduced working time compared with that of a full-time worker constitutes an objective criterion allowing a proportionate reduction of the rights of the workers concerned. ${ }^{16}$ In that way, the pro rata temporis principle incorporates its own objective justification. Notably, as this Framework Agreement does not apply to statutory dependent child allowances, it may be possible that the pro rata temporis principle is not interpreted as strictly as it is done here.

The Greenfield case concerned the calculation of payment in lieu upon termination of the contract for paid annual leave not taken. ${ }^{17} \mathrm{Ms}$ Greenfield worked under a contract of employment which stipulated that the working hours and days differed from week to week. The remuneration payable for any week varied according to the number of days or hours of work performed. Based on varying weekly working hours, a dispute arose about the payment in lieu for paid annual leave not taken upon the termination of Ms Greenfield's employment contract with her employer. In dispute was whether the Framework Agreement in conjunction with Art 7 Directive 2003/88/EC on working time requires a Member State to recalculate the amount of paid annual leave - even retroactively over the whole year - according to the worker's (flexible) work pattern. The CJEU ruled that the entitlement to paid annual leave must be calculated with regard to the work pattern specified in the contract. However, already accrued paid annual leave - a social right which the CJEU is keen on protecting - cannot be influenced by any later alterations as to the number of working hours. That means that in case the working hours increase, paid annual leave increases accordingly. Following the CJEU, already accrued

12 Case C-476/12 Österreichischer Gewerkschaftsbund ECLI:EU:C:2014:2332.

13 Case C-281/97 Krüger ECLI:C:EU:1999:396, para 16.

14 Case C-4/02 and C-5/02 Schönheit and Becker ECLI:EU:2003:583, paras 90-91.

15 Case C-486/08 Zentralbetriebsrat der Landeskrankenhäuser Tirols ECLI:EU:C2010:215, para 33.

16 Unlike a protective helmet, as the AG in her Opinion notes, para 25para 24.

17 Case C-219/14 Greenfield ECLI:EU:C2015:745. 
rights cannot be taken away, therefore EU law requires a new calculation of rights to paid annual leave to be performed only for the period of work during which the worker increased the number of hours worked. This case is of practical importance, making clear that once acquired, a worker may not be deprived of her rights granted by EU law.

The calculation of the amount of occupational pension accrued by part-time worker who left the undertaking before the occurrence of the pensionable event was subject in the Kleinsteuber case. ${ }^{18}$ Ms Kleinsteuber was employed between October 1990 and May 2014 in various positions, both full-time and part-time. Her rates of activity were between 50 and $75 \%$ of the activity of a full-time employee. Having reached the age of 55 , she enjoys the right to an occupational pension. However, she challenges the way in which her employer calculated the pension. The CJEU was asked to answer whether it is compatible with the Framework Agreement in conjunction with Art 4 Directive $2006 / 54 / E C$, to determine the amount of an occupational pension, to distinguish between employment income falling below the ceiling for the calculation of contributions to the statutory pension scheme and employment income above that ceiling. The alternative, which Ms Kleinsteuber suggested, would treat income from part-time employment by calculating first the income payable in respect of corresponding full-time employment. However, according to the CJEU, the employer's method to calculate the occupational pension scheme does not result in discrimination against part-time workers. It seems that, based on a strict application of the pro rata temporis principle, the rate was $71.5 \%$, i.e. the ratio between worker's actual years of service throughout her career and the years of service of a worker worked full-time during her entire career. Taking into account the worker's actual years of service is an objective criterion unrelated to any discrimination, allowing her pension entitlement to be reduced proportionately. ${ }^{19}$ When it comes to calculating benefits, the CJEU quite easily seems to accept the national methods adopted, provided, however, they are transparent and the method itself is non-discriminatory, even if leading to different outcomes. The principle of non-discrimination does not require that part-time and full-time workers benefit from the same outcome even if on a pro rata temporis basis. Whether this can be considered 'fair' can be debated, but the method itself is objective.

\section{Relation with social security benefits}

Although the following cases deal with social security schemes, not being employment conditions within the Framework Agreement, and in particular the methods of calculation thereof, these cases are relevant for the CJEU's interpretation of indirect discrimination and the difficulties with providing statistical evidence.

The Cachaldora Fernández case on the method of calculating the invalidity pension concerned the interpretation of Directive $79 / 7$ on the principle of equal treatment

18 Case C-354/16 Kleinsteuber ECLI:EU:C:2017:539.

19 Case C-4/02 and C-5/02 Schönheit and Becker ECLI:EU:2003:583, para 91. 
for men and women in matters of social security and Framework Agreement. ${ }^{20} \mathrm{Ms}$ Fernández worked full-time and part-time between 1971 and 2010 - except between 1998-2002 - and contributed to the social security system. She disagrees about the way her invalidity pension has been calculated, and in particular, the reference period, as her part-time employment falls largely within the eight year reference period used to calculate the actual pension..$^{21}$ The question is whether the Directive excludes provisions which provide that the contribution gaps existing within the reference period calculating a contributory invalidity pension, after having worked part-time, are taken into account at the level of the minimum contribution bases applicable at any time, reduced as a result of the reduction of that employment. For gaps during full-time employment, or in case someone has not worked at all, no such reduction is made. The CJEU found that the Spanish rule was not applicable to all part-time workers; it only applied to workers who have had a gap in their contributions during the reference period of eight years preceding the date of the event giving rise to the invalidity, when that gap followed a period of part-time work. ${ }^{22}$ The CJEU also emphasised that some women might even benefit, in particular if they have worked part-time before the reference period while working full-time during the reference period; their pension would then be overvalued in relation to the contributions actually paid. Thus, this cannot lead to the conclusion that the group of disadvantaged workers is mostly female.

What is problematic in this case is that the invalidity pension is not an employment condition under the Framework Agreement on Part-time Work, and that, therefore, it is not possible to compare between full-time and part-time workers. The only option is to argue that there has been sex discrimination, but that means that the applicant has to produce evidence proving that indeed a larger proportion of women than men are hit by the rule. Interestingly, following an example the Commission provided, where a worker during the reference period worked part-time for four years, full-time for six months, ceased her occupational activity for three years and then worked full-time for another six months, the period of inactivity here will be assimilated to a situation of having worked full-time (i.e. four years full-time work even if only actually worked full-time for one year). Even though Ms Fernández has worked full-time for most of the time (notably, the applicant contributed to the system for 39 years, three years and ten months of which part-time), except before the occurrence of event giving rise to invalidity, she is 'punished' for working part-time.

In Espadas Recio, on unemployment benefits of so-called 'vertical' part-time workers, Ms Espadas Recio, after having worked as a cleaner between 1999 and 2013, became unemployed after her employment contract was terminated. ${ }^{23}$ Based on Spanish law

20 Case C-527/13 Cachaldora Fernández ECLI:EU:C2015:215.

21 Period from 2002 until 2010 and taking for the period from 2002-2005 only the minimum contribution bases.

22 Case C-123/10 Brachner ECLI:EU:C:2011:675, para 56 and Case C-385/11 Elbal Moreno ECLI:EU:C:2012:746, para 29.

23 Case C-98/15 Espadas Recio ECLI:EU:C2017:833. 
on the method for calculating her unemployment benefit, she was granted a benefit of 120 days, extended to 420 days after filing a complaint. Still not satisfied, she argued in court that she, as a 'vertical' part-time worker, i.e. someone who concentrates working hours on certain days of the week rather than working on every working day of the week, 'horizontal' part-time worker has been treated differently. Ms Espadas Recio paid for six full years preceding her termination, but national law at issue permits only the days worked to be taken into account and not the entire contribution period, thus the duration of that benefit is reduced because only days worked are taken into account, even though the contribution period is longer. 'Horizontal' part-time workers or full-time workers, on the other hand, are treated more favourably. The majority of vertical part-time worker is women, adversely affected by that national law. According to the CJEU, although the contributions are paid pursuant to an employment relationship, the unemployment benefits are paid because of the law determining so, similar to a state-administered social security scheme and cannot be considered 'employment conditions'. Addressing the issue of indirect discrimination, the CJEU emphasizes that this case differs from the Cachaldora Fernández case, dealt with earlier, because (1) the CJEU did not have irrefutable statistical information regarding the number of part-time workers who had had a gap in their contributions or showing that that group of workers was principally made up of women and (2) the provisions had random effects, since some part-time workers could even benefit from the application of that provision. In Espadas Recio, it seems relevant that the statistical information produced is not contested. And, regarding the statistical information, the data covers 'vertical' and 'horizontal' part-time workers equally, indicating that in both groups there is a greater proportion of women than men that will be adversely affected. Thus, there is a difference in treatment to the detriment of women.

As Advocate General Sharpston emphasized, on many occasions the CJEU has ruled that because the statistical data relating to part-time workers in general could not demonstrate that women comprised the great majority in the group of part-time workers, not all situations led to indirect discrimination. Unlike in the Espadas Recio case, in the Fernández case, the precise group of part-time workers could not be clearly identified. As the Advocate General notes, the Spanish rule does take into account (i) the period during which contributions are made by the worker and her employer, (ii) the amount of those contributions and (iii) the working hours of the worker concerned, but only for full-time workers and 'horizontal' part-time workers. The measurements should therefore equally apply to 'vertical' part-time workers.

\section{EU case law on fixed-term work}

Over the past five years, more cases dealt with fixed-term employment (most them in Spain) than with part-time work, addressing various employment conditions, some of which were ruled discriminatory while others not. 


\section{Length-of-service increments}

The Regojo Dans case addressed three-yearly length-of-service increments. ${ }^{24}$ Applicant was employed as non-permanent member of staff since March 1996, holding the post of head of the secretariat of a Permanent Member of the Council. In January 2012, she claims that she had a right to receive three-yearly length-of-service increments. National legislation excludes, without objective justification, non-permanent staff from the right to receive three-yearly length-of-service increments granted to career civil servants. Obviously, three-yearly length-of-service increments constitute employment conditions. Thus, non-permanent staff has to be compared with a career civil servant. According to the Spanish government, non-permanent staff constitutes a professional category distinct from other categories of civil servants. And unlike career civil servants who are selected, non-permanent staff are appointed on a discretionary basis in order to carry out specific, non-permanent duties entailing trust or special advice. Termination of their employment is also discretionary and occurs automatically on termination of the appointment of the postholder for whom the duties are discharged. In case the national court rules the two types of workers to be comparable, it has to be assessed whether the difference can be objectively justified. The CJEU rules that there is, however, no objective ground where career civil servants on secondment can and do hold posts reserved for non-permanent staff while receiving the three-yearly length-of-service increments. This would be contrary to the argument that the particular nature of the duties entailing trust and special advice justifies a difference in treatment.

\section{Special leave}

In Vega González, the CJEU addressed the special leave for the election to the public office to serve as a member of parliament. ${ }^{25}$ Granting special service leave is part of the employment relationship and hence an employment conditions. Following the CJEU, it is important to identify whether there is a comparable permanent worker which performs the same or similar work. There is a difference of treatment between fixed-term workers and permanent workers, since the latter may be granted special service leave whilst a fixed-term worker must resign from his post in order to hold the same office. The national judge has to decide whether Ms Vega González is in a comparable situation as a permanent worker. Spain argued that it was the worker's deliberate and unilateral decision to take special leave because of being elected to the public office. The CJEU does not accept this reasoning, since a permanent worker in the same situation would have been faced with the same need. Furthermore, there is no guarantee that the person will be elected. An interesting point AG Sharpston makes in reaction to this statement is that the reason why the worker wants to take leave is entirely irrelevant.

24 Case C-177/14 Regojo Dans ECLI:EU:C:2015:450.

25 Case C-158/16 Vega González ECLI:EU:C:2017:1014. 
The reasoning brought forward by the Spanish government is akin to claiming that, since a female worker's employer is not (at least normally) involved in her decision to become pregnant, she should therefore not be able to benefit from maternity leave'. While the national court must assess whether the fixed-term worker is in a comparable situation as a permanent worker, the CJEU adds that, in case the court comes to such a conclusion, the predictability of the end of the employment relationship, could, in principle, constitute precise and concrete factors capable of justifying inequality of treatment as regards the granting of special service leave, such arguments do not apply in the underlying situation where the post has been occupied for more than four years by the same temporary worker. Principally, the CJEU sees no reason why such leave could not be granted to a fixed-term worker, provided the job has not been abolished or filled by an established civil servant.

\section{Notice period}

In the Nierodzik case, a dispute arose about the notice period for terminating a fixed-term employment contract. ${ }^{26}$ From May 1986 until February 2010, Ms Nierodzik was employed, mostly on a permanent employment contract until the contract was terminated by mutual agreement, as the employee wished to take early retirement. However, at the same time a fixed-term contract to work part-time was concluded for the period from February 2010 until February 2015. That contract contained a clause based on which the employer could unilaterally terminate the contract with a two-week notice period, without justification, which the employer invoked in April 2012. Polish law provides for fixed-term contracts concluded for longer than six months, a notice period of two weeks, and for permanent contracts a notice period because two weeks and three months. The CJEU emphasizes that the principle of non-discrimination prevents the employer using such an employment relationship to deny those workers rights which are granted to permanent workers. ${ }^{27}$ Conditions relating to dismissals, including notice periods, are employment conditions. The fact that the applicant occupied the same post before she entered into a fixed-term contract may support the fact that she was in a comparable situation to a person with a permanent contract. Thus, applying different notice periods constitutes different treatment. As the difference of treatment between the two types of employment contracts lies in their length and the stability of the employment relationship, relying on the mere temporary nature of the employment is not capable of constituting an objective ground. It is in particular this ground to which the principle of non-discrimination applies.

26 Case C-38/13 Nierodzik ECLI:EU:C:2014:152.

27 Case C-444/09 and C-456/09 Gavieiro Gavieiro and Iglesias Torres ECLI:EU:C:2010:819, para 48. 


\section{Payment of compensation}

Most of the fixed-term work cases deal with the payment of compensation. To start, different types of compensation for terminating fixed-term employment contracts applied in the Carratù case: compensation for the unlawful insertion of a fixed-term clause into an employment relationship payment in respect of unlawful termination of a permanent employment relationship. ${ }^{28}$ The question was whether the two must be treated in the same way. From 4 June until 15 September 2004, Ms Carratù was employed to replace a member of staff employed with Poste Italiane. After her employment terminated, she sent a letter by registered post from 21 September 2004, that she is available for work. As the conciliation procedure was unsuccessful, she brought proceedings against Poste Italiane in September 2008. In a ruling from 25 January 2012, the Italian court determined that the fixed-term clause has been unlawful and that Ms Carratù had a permanent employment relationship as of 4 June 2004. As the concept employment conditions has not been expressly defined by Framework Agreement on Fixed-term Work, the CJEU relies on its case law on the Framework Agreement on Part-time Work. Clearly, the compensation paid on account of the unlawful insertion of a fixed-term clause into an employment contract is compensation paid on account of employment. But, is Ms Carratù in a comparable situation as a permanent worker ${ }^{29}$ Not addressing this issue, the CJEU stresses that the two compensations differ: the first is paid to compensate for an unlawfully concluded employment contract, whereas the second is paid to employees who have been dismissed. Thus, the principle of non-discrimination did not apply.

In the Pérez López case, the CJEU again found that there was no comparable worker, because of the difference between statutory and contractual employment. ${ }^{30}$ Between February 2009 and March 2013, Ms Pérez López was without interruption employed as a nurse at a university hospital in Madrid (seven renewed fixed-term contracts). National legislation fails to provide compensation for termination of a contract of employment to occasional regulated staff while such compensation is paid to comparable workers employed under contracts for occasional employment. The difference in treatment, the CJEU established, is not based on the fixed-term or permanent nature of the employment relationship, but whether the fixed-term nature of the contract is statutory or contractual. Applicant wanted the CJEU to compare between different categories of fixed-term workers which falls outside the scope of the principle of non-discrimination. That would be different if the referring court finds that workers employed under a permanent contract doing comparable work are paid compensation for termination of a contract of employment, whereas such compensation is not paid to fixed-term workers. While in line with the Framework Agreement the CJEU's ruling is correct, it nevertheless creates

28 Case C-361/12 Carmela Carratù v Poste Italiane SpA ECLI:EU:C:2013:620.

29 Case C-395/08 and C-369/08 Bruno and Others ECLI:EU:C:2010:329, para 46; Case C-302/11 to C-305/11 Valenza and Others ECLI:EU:C:2012:646, para 42.

30 Case C-16/17 Pérez López ECLI:EU:C:2016:679. 
the problem that the status of the worker, i.e. whether the employment relationship is of a statutory or contractual nature, becomes decisive for the level of protection granted. This is particularly worrisome where the state increasingly excludes some forms of employment because of the rights and obligations that would otherwise be involved.

Also in Diego Porras, the legislation failed to provide compensation for terminating a fixed-term contract while allowing compensation to comparable permanent workers. ${ }^{31}$ Ms Diego Porras' contract, after having been employed on several fixed-term contracts, was terminated so as to allow the reinstatement of the worker she replaced. The Spanish court raises doubts as to the compensation for termination of the employment relationship: the legal termination of a permanent contract is 20 days' salary for each year of service, while only 12 days' salary for each year of service if on a fixed-term contract. It is clear, so the CJEU, that compensation is an employment condition. But is there a comparable permanent worker? It follows from the file submitted to the CJEU that the applicant did work similar or identical to that of a permanent worker, i.e. she was replacing someone with a permanent contract for seven years who was on leave to carry out trade union work. As to the objective justification of the difference in treatment, the CJEU made clear that neither the temporary nature nor the absence of any provision regarding granting compensation constitute objective grounds.

The Grupo Norte case, in which mother and son shared a job due to the mother's partial retirement, the CJEU faced the question whether the situation of a fixed-term worker and a permanent worker in terms of compensation on termination of the contract can be considered as comparable. ${ }^{32}$ Although it is for the national court to determine whether Mr Moreira Gómez, who was employed under a fixed-term relief employment contract, was in a situation comparable to that of permanent employees, the CJEU stressed that he occupied the same post of cleaner at the hospital as the worker he partially relieved pending her full retirement. The situation of Mr Moreira Gómez is therefore comparable to that of a permanent worker. Addressing whether there is an objective reason justifying the difference in treatment, Spanish law offers, as we have seen in Diego Porras dealt with above, different compensations: the legal termination of a permanent contract granting 20 days' salary for each year of service when terminating a permanent contract and 12 days' salary for terminating a fixed-term contract. The Spanish government argues that, and the CJEU agrees, there are different aims that underlie these compensations: compensation for the expiry of a fixed-term contract (i.e., a foreseeable event) and compensation in the event of collective dismissal, paid to compensate for the unforeseen nature of the termination of the employment relationship, to compensate any frustration that may arise due to legitimate expectations the worker may have had at that date as regards the stability of that relationship. In addition, the compensation is paid to fixed-term and permanent workers alike; hence, there is no unequal treatment.

31 Case C-596/14 Diego Porras ECLI:EU:C:2016:683.

32 Case C-574/16 Grupo Norte ECLI:EU:C:2018:390. 
Montero Mateos, ruled on the same date as the Grupo Norte case, concerned the situation of Ms Montero Mateos who worked as an assistant in a residential home for elderly persons run by an agency on the basis of a temporary replacement contract to replace a permanent worker. ${ }^{33}$ That contract was converted to a temporary replacement contract to fill a vacant post temporarily. After a recruitment procedure, the post was assigned to a person and thus Ms Montero Mateos' temporary replacement contract ended. She claimed that she performed the same tasks as the person who had been hired, however without having received any compensation whereas such compensation is paid to the termination of a fixed-term and permanent contract. It is clear from the evidence available to the CJEU that Ms Montero Mateos carried out the same tasks as an assistant in a residential home for elderly persons as those that the person selected was recruited to carry out and the purpose of the selection was precisely to fill her post. Nevertheless, not granting compensation to workers on temporary replacement contracts can be justified by precise and specific factors, namely that it was clear that once a replacement was found, Mrs Montero Mateos' contract would automatically end. While indeed fixed-term contracts automatically come to an end either on a specific date or on the occurrence of a specific event, and there may also be no legitimate expectation with the fixed-term worker that his employment will be continued, not paying a compensation at all for that 'objective justification' seems to contribute to the fact that fixed-term work is a cheaper alternative to full-time employment. The latter becomes even more the case where an increasing number of rights are not granted to fixed-term workers because of the objective justification that there contract comes, in one way or the other, to an end. A possible alternative approach could be to pay a compensation for the fact that the worker may need a financial buffer to cope with unemployment or to undergo training to find a new job.

\section{Right to reinstatement}

The last case to be dealt with is Vernaza Ayovi, which concerned the question whether there is a right to reinstatement. ${ }^{34}$ Ms Vernaza Ayovi was employed as a nurse from May 2006, first on a fixed-term, later on a permanent contract. After being on leave on personal grounds for more than a year, in June 2014, she asked to be reinstated, but was informed that there were no suitable or equivalent nursing positions in her previous specialism available. As a result, Ms Vernaza Ayovi participated in five unsuccessful internal recruitment procedures. Finally, awarded a part-time, late-shift position on the basis of a 'non-permanent contract of indefinite duration', she was unwilling to accept any change to the employment conditions applicable prior to her leave and in May 2016 she rejected the duty roster which had been issued to her. She then failed to turn up for work. She was dismissed in July 2016 on disciplinary grounds for absence

33 Case C-677/16 Montero Mateos ECLI:EU:C:2018:393.

34 Case C-96/17 Vernaza Ayovi ECLI:EU:C:2018:603, compare with Opinion AG Kokott. 
from work without leave. In case of an unlawful dismissal a permanent (public servant) worker has the right to reinstatement, whereas such a right is not granted to fixed-term workers, leading to the question whether there is a difference in treatment. Given that notice periods are employment conditions, the CJEU, by analogy, rules that also the right to reinstatement is an employment condition. As to the comparability of the fixed-term worker with the permanent worker, the CJEU emphasized that they were in a comparable situation. With a view to the question whether this difference can be justified, the general rule applicable in the event of 'wrongful' or 'unlawful' dismissal determines that the employer may choose to reinstate the worker; and only in exceptional circumstances, the worker must be reinstated. While the method of recruitment itself cannot justify a difference in treatment, the CJEU found that considerations based on the characteristics of the law governing the national civil service, such as protecting permanent workers who passed a competition for recruitment to the public service by offering job stability, can. The conditions of impartiality, efficiency and independence of the administration, which have no counterpart in standard employment law, imply a certain permanence and stability of employment explain and justify the limitations on the power of public employers unilaterally to terminate employment contracts. Consequently, the automatic reinstatement of permanent workers takes place, factually and legally, in a significantly different context to that in which non-permanent workers find themselves. Thus, the unequal treatment is justified. Unlike the CJEU, Advocate General Kokott saw no reason why a fixed-term worker could not be reinstated for the remaining term of her fixed-term contract. The purposes of reinstatement are to put right an unlawful act by the employer the consequences of which are far-reaching given its impact on the continued existence of the employment relationship and to satisfy the worker's legitimate expectation that her employment relationship will continue in being for the duration of its normal term. From that point of view, there is no difference between a permanent and fixed-term worker. Furthermore, the unlawful termination by the employer of an ongoing employment relationship is no less unlawful when it affects a fixed-term worker than when a permanent worker falls victim to it. She further emphasises that there is no danger of any principles of public service employment being adversely affected where a fixed-term work who has been wrongfully dismissed is granted a right to reinstatement (she does not acquire permanent employment nor does the status of fixed-term worker change in another way).

\section{Analysis and conclusion}

After having discussed the recent case law on the non-discrimination principle in the context of part-time and fixed-term work over the past five years, it becomes clear that the three limitations of that principle as indicated above, still are reflected in the cases.

In relation to the concept employment conditions, it becomes clear that, in particular in relation to part-time work where a work-related benefit, such as a social security 
benefit, which is not considered an employment condition, leads to a situation in which female workers need to ground their discrimination claim on the basis of Directive $79 / 9$ on the progressive implementation of the principle of equal treatment for men and women in matters of social security. There has thus been a shift from the type of employment relationship to the aspect of gender as a potential ground on which the different treatment can be based. However, and this can be disadvantageous as we have seen in the Cachaldora Fernández case, because a 'gender lens' is put on, female workers face the difficulty in producing the right statistical evidence. It is interesting to see that the CJEU accepted data from different groups of part-time workers (vertical vs horizontal), because it can be assumed that this only is the case where there is also a group of comparable full-time workers with whom the part-time worker must be compared. However, this would mean that the data must take into account different forms of part-time work organisation. Nevertheless, a measure like the one in the Cachaldora Fernández case, is particularly harmful for workers working part-time, even where the method to calculate an invalidity pension is objective, its effect may be detrimental to those who, during the reference period applied prior to the event that led to the right of such pension. The CJEU's argument that not all part-time workers were affected but only those who had a gap during the reference period, fails to acknowledge that it is still the part-time employment that has led to the reduction of the benefit, even if most of the time work was performed on a full-time basis. Showing less favourable treatment of female workers is limited to the applicable employment condition at hand and does not cover a broader range. The exclusion of social security form the Framework Agreement and instead using a gender lens is not able to redress any disadvantages and does not achieve any structural change.

In line with this, the CJEU's reasoning in the Mascellani case, where it said that the conversion from full-time to part-time is different than the other way round, is problematic as well. Where a full-time employment relationship has been converted into a part-time employment relationship, because the worker had personal reasons, like family and/or care obligations, it is true that this results in a decrease in the remuneration and reduces any rights and benefits accordingly. However, if that relationship is reconverted into one of full-time, this may increase the remuneration and thus improve the worker's livelihood, but it creates a problem of time for the worker concerned. Even though many situations, such a care for children or other family members can be done by professionals, workers may have reasons not to outsource these tasks. A unilateral reconversion then would take away a choice on behalf of the worker.

While considering a right or benefit to be an employment condition is rather unproblematic in the context of fixed-term work, at least as far as the abovementioned cases are concerned, the comparability of the fixed-term worker with a permanent worker might be problematic if there is no 'opposite' worker. It is not possible to compare between different categories of fixed-term workers, or part-time workers, as the Framework Agreement aims to guarantee non-discrimination in comparison with a comparable permanent worker. What the cases above show is that while there may 
be comparable workers, where the purposes of the applicable employment conditions, such as the compensation in case of termination of the employment contract, differ, there is nobody to compare with. While this seems a reasonable conclusion, the Montero Mateos case shows that the fact that a fixed-term contract ends on the occurrence of a specific event, even if it is unknown when this specific event will happen, this can be an objective reason justifying the fact that no compensation is paid at all. Such termination is not comparable with, for instance, an unlawful termination of the contract. However, this also gives a reason to use fixed-term contracts as they, unless otherwise provided by national law, end automatically upon a certain date or the occurrence of a specific event while offering an objective justification for not paying a compensation in case of a replacement contract concluded until the post has been filled.

In the cases dealing with the pro rata temporis principle in the context of part-time work, the CJEU in some cases assumed that the applicable conditions was an employment condition. Also, where it was clear that the method to calculate certain benefits did not distinguish between part-time workers and full-time workers, no reference was made to a 'comparable worker' (assuming that the two were indeed comparable). The CJEU quite easily accepts a 'difference in treatment' caused by applying the pro rata temporis principle in part-time cases where the methods to calculate employment conditions are non-discriminatorily applicable. As long as the same methods to establish a particular payment, like dependent child allowance or occupational pension, are used for both the full-time and the part-time worker, the CJEU applies the pro rata temporis principle quite strictly. This seems to be in line with the principle that part-time workers are not to be treated less favourably than full-time workers are. Member States may of course provide more favourable rules if they wish.

Where a Member State allows a difference in treatment just because it concerns a part-time or fixed-term contract, the CJEU strictly applies the non-discrimination principle. In Nierodzik, the CJEU clearly ruled that the difference of treatment between the two types of employment contracts lies in their length and the stability of the employment relationship, and therefore, relying on the mere temporary nature of the employment is not capable of constituting an objective ground justifying a difference in treatment. The Pérez López case differs on this point, as here, where the difference in treatment, the CJEU ruled, is not based on the fixed-term or permanent nature of the employment relationship, but whether the fixed-term nature of the contract is statutory or contractual. Hence, applicant wanted the CJEU to compare between different categories of fixed-term workers and this falls outside the scope of the principle of non-discrimination.

\section{References}

Barnard C., EU Employment Law, $4^{\text {th }}$ ed., Oxford University Press 2012.

Davies A., EU Labour Law, Elgar European Law, Edward Elgar 2012. 
Davies A., Regulating atypical work: Beyond equality, in: N. Countouris, M. Freedland (eds.), Resocialising Europe in a Time of Crisis, Cambridge University Press 2013.

European Commission, Annual Growth Survey 2016: Strengthening the recovery and fostering convergence, Communication (COM) 2015.

\section{Cases}

Brachner, C-123/10, ECLI:EU:C:2011:675.

Bruno and Others, C-395/08 and C-369/08, ECLI:EU:C:2010:329.

Cachaldora Fernández, C-527/13, ECLI:EU:C2015:215.

Carmela Carratù v Poste Italiane SpA, C-361/12, ECLI:EU:C:2013:620.

Diego Porras, C-596/14, ECLI:EU:C:2016:683.

Elbal Moreno, C-385/11, ECLI:EU:C:2012:746.

Espadas Recio, C-98/15, ECLI:EU:C2017:833.

Gavieiro Gavieiro and Iglesias Torres, C-444/09 and C-456/09, ECLI:EU:C:2010:819.

Greenfield, C-219/14, ECLI:EU:C2015:745.

Grupo Norte, C-574/16, ECLI:EU:C:2018:390.

Kleinsteuber, C-354/16, ECLI:EU:C:2017:539.

Krüger, C-281/97, ECLI:C:EU:1999:396.

Montero Mateos, C-677/16, ECLI:EU:C:2018:393.

Nierodzik, C-38/13, ECLI:EU:C:2014:152.

Örebro läns landsting, C-236/98, ECLI:EU:C:2000:173.

Österreichischer Gewerkschaftsbund, C-476/12, ECLI:EU:C:2014:2332.

Pérez López, C-16/17, ECLI:EU:C:2016:679.

Regojo Dans, C-177/14, ECLI:EU:C:2015:450.

Schönheit and Becker, C-4/02 and C-5/02, ECLI:EU:2003:583.

Teresa Mascellani, C-221/13, ECLI:EU:C:2014:2286.

Valenza and Others, C-302/11 to C-305/11, ECLI:EU:C:2012:646.

Vega González, C-158/16, ECLI:EU:C:2017:1014.

Vernaza Ayovi, C-96/17, ECLI:EU:C:2018:603.

Wippel, C-313/02, ECLI:EU:C:2004:607.

Zentralbetriebsrat der Landeskrankenhäuser Tirols, C-486/08, ECLI:EU:C2010:215. 